\title{
Spy Schools: How the CIA, FBI, and Foreign Intelligence Secretly Exploit America's Universities. By Daniel Golden. NY: Henry Holt and Company, 2017.
}

Ed J. Hagerty

American Public University System

Follow this and additional works at: https://digitalcommons.usf.edu/jss

pp. 107-110

\section{Recommended Citation}

Hagerty, Ed J.. "Spy Schools: How the CIA, FBI, and Foreign Intelligence Secretly Exploit America's Universities. By Daniel Golden. NY: Henry Holt and Company, 2017.." Journal of Strategic Security 12, no. 1 (2019) :

107-110.

DOI: https://doi.org/10.5038/1944-0472.12.1.1731

Available at: https://digitalcommons.usf.edu/jss/vol12/iss1/5

This Book Review is brought to you for free and open access by the Open Access Journals at Digital Commons @ University of South Florida. It has been accepted for inclusion in Journal of Strategic Security by an authorized editor of Digital Commons @ University of South Florida. For more information, please contact digitalcommons@usf.edu. 


\section{Spy Schools: How the CIA, FBI, and Foreign Intelligence Secretly Exploit America's Universities. By Daniel Golden. NY: Henry Holt and Company, 2017.}




\section{Spy Schools: How the CIA, FBI, and Foreign Intelligence Secretly Exploit America's Universities. By Daniel Golden. NY: Henry Holt and Company, 2017. ISBN 978-1-627779-635-4. Photographs. Notes. Sources cited. Index. Pp. xxv, 324. \$30.oo.}

Most Americans are well aware that organizations like the Central Intelligence Agency (CIA) have long sought to recruit the best and brightest from the hallowed halls of our most respected academic institutions. The presence of such agencies on campuses has been a staple of higher education, except in instances where protests temporarily compelled universities to reject it, but the close relationship between those agencies and educational institutions has enjoyed a post-9/11 resurgence. The search for recruits, however, is benign in comparison to other activities being pursued on campuses. Thus, fewer Americans are aware of the extensive presence of both foreign and domestic operatives who are covertly engaged in clandestine activities on those campuses. It is precisely that sort of undisclosed activity that Pulitzer Prize winning journalist Daniel Golden seeks to bring to light in this work. None of this will be startling news to anyone in the intelligence community, although the details of operations may certainly enhance professionals' understanding of these kinds of activities. For the student, novice, or the general public, the narrative is likely to be more revealing. The ever increasing number of foreign students and foreign faculty members on American campuses makes the topic a compelling one to consider. In addition to a significant increase in the number of foreign-born faculty members now working in STEM and other fields on U.S. campuses, Higher Education institutions in the U.S. have also come to rely increasingly on the enrollment of foreign students as a way to financially subsidize the schools. Often, foreign students eagerly pay the full sticker price for tuition at prestigious schools, and as non-residents they pay more at public, taxpayer-supported institutions. Some schools even add an additional fee for international students.

Although most foreign students are merely seeking the best and most prestigious educational experience they can find, their presence in high numbers increases the possibility that at least some of them might be working for their nation's intelligence services. At the same time their presence opens an opportunity for U. S. Intelligence agencies to exploit those students for the agencies' own purposes. The same principle applies 
to faculty members. Thus, as Golden documents, both the counterintelligence and the positive intelligence missions are enjoying a robust run of activity on American campuses, often with the unwitting complicity of naive faculty members and administrators who either do not think in terms of potential intelligence threats, or in some cases choose to ignore them. Although, as Golden suggests, such activities might contaminate the traditional ivory tower paradigm of academic freedom among a normally open and independent scholarly community, some institutions simply choose to ignore the potential for espionage that stems from globalized academic connections because it is to their economic advantage to do so.

Golden's objective in this book was to "explore how and why intelligence services were targeting American higher education, and what the implications were for national security and academic freedom" (xvi). He divides his book into two distinct parts. Part one looks at instances of espionage on campuses, and part two examines U.S. attempts to exploit foreign students and the academic environment in general. Recognizing that both sides seek to milk the situation for all it's worth, Golden goes on to rely on his journalistic skills to uncover information and utilize case studies of specific individuals to illustrate various instances of how exploitation is actually accomplished. Many cases involve students or faculty members associated with the kinds of scientific and technology fields that deal with information that could provide some unique advantage to one side or another. Golden raises a valid point in questioning whether clandestine activities that contribute to national security simultaneously damage academic collaboration by heightening suspicions among professors that potential collaborators might be functioning with ulterior motives on behalf of a third party. Moreover, though his sample is a small one, Golden finds that recruiting our own professors as amateur spies seems not to yield very promising results. Whether from their reluctance or incompetence, Golden concludes that the lack of success has had a detrimental impact on academic culture and outweighs any small benefits that have been realized. Perhaps more damaging is that some professors, like their institutions, sometimes fall victim to the ultimate weakness of an ivory tower outlook and thus ignore or fail to recognize the potentially nefarious motives of foreign counterparts in their field. 
In terms of targeting foreign students, recruitment frequently relies on money as an incentive, and it is often a successful method for putting sources on the books, but the long-range prognosis for actually obtaining useful returns from those relationships is less certain. As for the targeting of foreign professors, Golden notes that one intelligence agent suggested that academic conferences were a more fruitful venue than campuses. The much publicized case of University of South Florida (USF) Professor Dajin Peng-whose story constitutes a significant segment of the bookillustrates that the possibilities for recruiting foreign faculty members are many, but are not always profitable. Peng's personal indiscretions and allegations of mismanagement at his university set him up nicely for an FBI approach. He was a tainted, but highly qualified candidate. A graduate of China's Institute of International Relations, Peng had extensive contacts in the Chinese intelligence community. He later received his doctorate at Princeton and moved on to a position at USF, where he established Florida's first Confucius Institute, whose branches are closely connected with the Chinese government. Naturally such an institution was of much interest to the FBI, and when Peng fell afoul of USF in the wake of several accusations of malfeasance, an FBI agent came quickly to his support. Though Peng preserved his job and tenured status at USF, he was punished with fines and suspensions, but without any criminal charges being lodged. The cost for that leniency was working against China on behalf of the FBI and CIA. The FBI efforts to salvage Peng's career were misguided, however, and he was so reluctant to spy for the agency that he never really provided any useful information at all despite his many trips to China. Later he even accused the FBI of orchestrating the charges against him in an effort to recruit him as a spy.

In conclusion, Golden relates an interesting, though sometimes unnecessarily speculative tale that provides a sound introduction to the relationships between the intelligence community and academia. Readers should take note, however, that it is a journalist's tale told in journalistic fashion. It is not the product of extensive scholarly research and it is based largely on news sources and other publically available materials supplemented by first-hand interviews. The interview material elevates the book to a higher level, although the deficiencies in the overall quality of the research undermine the academic quality of the work and frequently compel readers to accept the validity of interviewees' comments at face 
value. It is far from a fatal flaw though, as there is no reason to question the general thrust of the book or its conclusions despite those limitations.

Edward J. Hagerty, Ph.D., American Public University System 